\title{
酸無水物とエポキシドの硬化反応における種々の置換酸無水物の 反応性及ひ開環反応機構の解析
}

\author{
小又基彰*1・渡辺茂隆*1
}

（受付 1992 年 2 月 5 日・審査終了 1992 年 4 月 11 日）

\begin{abstract}
要 旨 酸無水物とエポキシドの硬化反応における酸無水物の反応性に対する置換基勃果（誘起効果，共鳴効 果, 立体効果) についての知見を得るために，第三アミンを促進剤に用いて，無水フタル酸及び無水マレイン酸の 各種置換体と，エポキシ化大豆油（内部エポキシド）との硬化反応を検討した。 エポキシ化大豆油と酸無水物の 2 次反応において, 電子吸引性の置換基 $\left(\mathrm{Cl}, \mathrm{NO}_{2}\right)$ の存在は酸無水物の反応性を高めた。，一方，電子供与性基 $\left(\mathrm{CH}_{3}\right)$ の存在は反応性を多少高め (4メチル無水フタル酸), あるいは低下させ (3-メチル無水フタル酸), 置換位置の連い で反応性が異なることか認められた。これらのことから, 酸無水物の反応性は, 置換基の誘起効果 (I 効果) の寄与

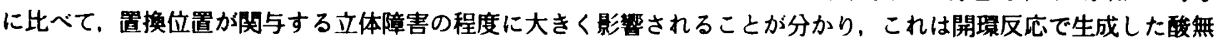
水物アニオンの分子構造に起因すると推定した。 また比较のために行った末端ェポキシドの, ビスフェノール A ジグリシジルエーテル (DGEBA) と, 酸無水物（無水フタル酸及びそのメチル置換体）の反応では, 酸無水物の開 橲反応 (0次反応) が律速となり、このとき酸無水物の反応性には大きな差は見られなかった。この結果に基づき， 睖無水物の開環反応機構を考察した。
\end{abstract}

\section{1 粕論}

第三アミンによるエポキシドと酸無水物の硬化反応機 構は, Fischer, 田中らにより研究がなされておりり ， 酸無水物のカルボニル基に, 促進剤の第三アミンが求核 付加することで反応は始まり，その結果，生成したカル ボキシルアニオンと，エポキシ基の反応が律速段階とな り，2 次反応で進行すると言われている(1).2)，この反心に おける酸無水物の反応性は，酸無水物が開環すること で，生成したカルボキシルアニオンの反応性に起因する と考えられる。したがって，酸無水物の反応性を究明す るには，その開環反応機構を知ることが肝要になるが， これについては，置換基をもたない酸無水物を対象に， 説明されているに過ぎず) 3)，置換基を有する場合は触 れられていない点から，この場合に適応できる反応機構 を解明し，酸無水物の反応性との関連性を，明らかにす ることは重要と思われる.

ところで，置換基を有する酸無水物の開環反応は，二 種のアニオンの生成が考えられるが，㯰換基の I 効果及 び共鳴効果により，酸無水物基に対する第三アミンの求 核位置はほぼ限定され，特定のアニオン生成が優先する と推察できる.このカルボキシルアニオンに対する置換 基効果は, 活性点への I 効果, 共鳴効果, 立体効果であ

*1 茨城大学工学部システム工学科（③16 日立市中成沢町 412-1)
り，これらの相互作用で酸無水物の反応性は定まるすの と考えられる.

前報)では無水フタル酸に比べて，そのメチル置換体 （3 位，4 位の混合物）の反応性が低いことが認められ, その結果から, カルボキシルアニオンの反応性は, メチ 儿基の I 効果の寄与に比へてて, メチル基の立体障害の程 度に, 大きく影響されることを推察した. このことから， 無水フタル酸のメチル置換体（3 位及び 4 位）の開環反 応機構を考えると，第三アミンは，メチル基から離れた 側のカルボニル炭素（酸無水物基）に求核付加し, 開罯 することになる，その結果，生成したアニオンは活性点 とメチル基が，隣接または，環の炭素原子を一つ隔てた 位置になり、メチル基が立体障害となるような構造にな る.

この推論を進めるために本報告では，無水フタル酸及 び無水マレイン酸の各種置換体と，エポキシドとの硬化 反応を行い, 置換基や置換位置の違いが, 酸無水物の反 応性にどのような影響を及ぼすか，その関連性について 検討し，上述の酸無水物の開環反応機構を考察した。

\section{2 実験}

\section{1 試料}

エポキシ化大豆油 (EpSO), ビスフェノールAのジグ リシジルェーテル (DGEBA), 及び促進威のトリェチル アミン (TEA) は前報)のものを使用した．酸無水物硬化

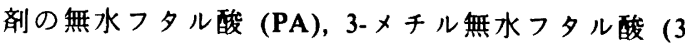


Me-PA), 4-メチル無水フタル酸 (4Me-PA), 3-ニトロ無水 フタル酸 $\left(3 \mathrm{NO}_{2}-\mathrm{PA}\right)$, 及び無水マレイン酸 (MA), クロ ル無水マレイン酸 (Cl-MA), メチル無水マレイン酸 (Me-MA), ジメチル無水マレイン酸 (DMe-MA) はすべ て市販品をそのまま用いた。 なお, 試料の配合組成は無 溶媒系, 溶媒系ともに, EpSO（または DGEBA）: Anhydride : TEA のモル比が, $1: 1: 0.2$ になるように調製し た.

\section{2 示差走査熱量計法 (DSC)}

定温 DSC 測定は $60 \sim 155^{\circ} \mathrm{C}$ の所定温度で行った。 昇 温 DSC 測定は室温から $200^{\circ} \mathrm{C}$ または $250^{\circ} \mathrm{C}$ までの範囲 を測定した。これらの测定法及びデー夕解析法は，前 報けに準じて行った。

\section{3 結果と考察}

\subsection{DGEBA（末端エポキシド）に対する無水フタル 酸及ひその置換体の反応性}

反応温度 $80^{\circ} \mathrm{C}$ の反応率一反応時間の関係を Fig. 1 に 示す. 各酸無水物 (PA, 3Me-PA, 4Me-PA) 系の反応率の 時間変化はほぼ等しくなり, 反応粱が約 $50 \%$ までは酸 無水物の濃度に関係なく, 反応は 0 次反応的に進行して いる. Fig. 1 の結果は, 酸無水物の開環反応が律速段階 となった前報”の結果に，類似することから０次反応之 して取扱い，Fig. 1 の直線の傾きから反応速度を求める

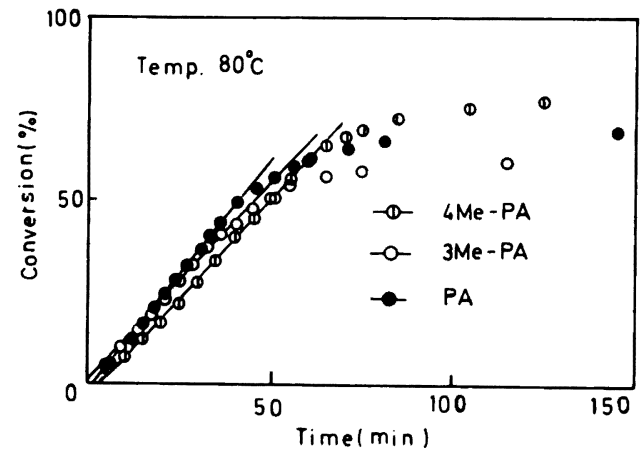

Fig. 1. Time-conversion curves for the curing of DGEBA/Phthalic anhydrides/TEA system.
と, Table 1 に示すように, 酸無水物によらず近い值が得 られた。

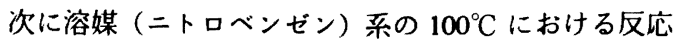
率 一応時間の関係を Fig. 2 に示す. なお, 溶媒系の組 成 (mol/100 gMix.) は, DGEBA: $0.1725 \pm 0.003 \mathrm{~mol}$, anhydride: $0.1754 \pm 0.007 \mathrm{~mol}$, TEA: $0.036 \pm 0.003 \mathrm{~mol}$, $\mathrm{C}_{6} \mathrm{H}_{5} \mathrm{NO}_{2}: 0.2731 \pm 0.014 \mathrm{~mol}$ である. Fig. 2 の $3 \mathrm{NO}_{2}-\mathrm{PA}$ を除いた 3 者は Fig. 1 に類似した結果が得られ，反応は 反応率 50〜60\%までほぼ 0 次的に進行した。このこと から 0 次反応として取扱い, 反応速度 [p(反度度) $\cdot \mathbf{s}^{-1}$ ] を求めると, $3 \mathrm{Me}-\mathrm{PA}$ は $3.06 \times 10^{-4}, \mathrm{PA}$ は $3.33 \times 10^{-4}$, 4Me-PA は $3.79 \times 10^{-4}$ の互いに近い值が得られた。 ま た， $3 \mathrm{NO}_{2}$-PA は反応温度 $\left(70^{\circ} \mathrm{C}\right)$ で完全に溶解しないこ ともあり, 反応は約 50\% の低反応率で終了したが, 反応 の進行は他の酸無水物より速く, 反応性が高いことが分 かり, 反応次数は 2 次式にほぼ適合した。

以上のように無水フタル酸系の反応では, 反応が不完 全であった $3 \mathrm{NO}_{2}-\mathrm{PA}$ を除いてすべて 0 次反応となり, 酸無水物の開環反応（式 (1)）が律速反応と推定される. これまでに，DGEBA との反応で開環反応が律速となっ た酸無水物は, 前報)のものを含めると, Me-THPA, MeHHPA, (R) ${ }_{3}$-THPA, PA, 3Me-PA, 4Me-PA で, これらは 母体酸無水物か, そのメチル置換体であり，各酸無水物 の反応性には大きな差は見られなかった。このように開

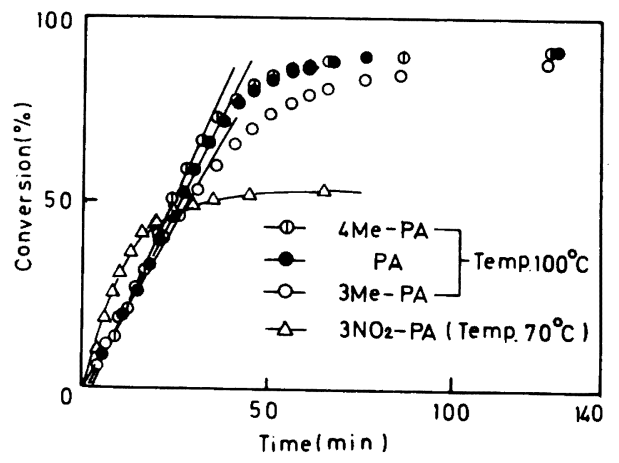

Fig. 2. Time-conversion curves for the curing of DGEBA/Phthalic anhydrides/TEA (nitrobenzene solvent system).

Table 1. Zero order rates for the curing of DGEBA/Anhydride/TEA (1:1:0.2 mol)

\begin{tabular}{|c|c|c|c|c|c|c|c|}
\hline \multirow{3}{*}{ Anhydride } & \multicolumn{5}{|c|}{$V \times 10^{-4}\left(\right.$ conversion $\left.\cdot \mathrm{s}^{-1}\right)$} & \multirow{3}{*}{$\begin{array}{c}E \\
\left(\mathrm{kcal} \cdot \mathrm{mol}^{-1}\right)\end{array}$} & \multirow{3}{*}{$A$} \\
\hline & \multicolumn{5}{|c|}{ Temperature $\left({ }^{\circ} \mathrm{C}\right)$} & & \\
\hline & 70 & 80 & 90 & 100 & 110 & & \\
\hline 3Me-PA & 0.886 & 1.77 & 3.16 & 6.46 & - & 16.6 & $3.51 \times 10^{6}$ \\
\hline 4Me-PA & 0.836 & 1.79 & 3.78 & 7.37 & - & 18.5 & $5.42 \times 10^{7}$ \\
\hline PA & $1.06^{\mathrm{a})}$ & 2.10 & 4.49 & 7.61 & 14.1 & 16.8 & $5.36 \times 10^{6}$ \\
\hline
\end{tabular}


環反応が律速反応 (0 次)になった場合は, 各酸無水物の 反応性は大差ない結果が得られたことから，酸無水物の 開環反纫機構を以下のように推察した。

メチル基（電子供与性基）を置換基にもつ酸無水物の 開環反応は, メチル基の I効果により，置換基に近いカ ルボニル炭素（酸無水物基）の電子密度が, 多少高まる ために，それよりは比較的電子密度の低い，遠方のカル ボニル炭素を，第三アミンが選択的に求核攻撃し，開環 することが考えられる，その際，第三アミンの求核付加 は母体環より突出している酸無水物基の構造から察し, 置換基による立体障害の影響はほとんど受けないすのと 考えられ，また，上述の選択的な求核付加を考慮すると， メチル置換体の開環反応速度は, 置換基を持たない母体 酸無水物 (PA) の值に近いことが言える.

一方, DGEBA 亡の反応で電子吸引性の置換基を有す る $3 \mathrm{NO}_{2}-\mathrm{PA}$ は， 母体酸無水物及びそのメチ儿誘導体よ りあ反応性が高く，2 次反応に適合するなど，他の酸無 水物と異なるが, 反応温度で完全に溶解しないこともあ り, 詳しいことは分かっていない,ここで, 電子吸引性 の置換基を有する酸無水物の開環反応を推測すると, 第 三アミンの求核位置は置換基の電子吸引性により, 置換 基に近いカルボニル炭素の電子密度がより低くなるの で，この炭素を主に求核攻撃することが考えられる。こ の開環反応は母体酸無水物及びそのメチル置換体に比へ て, カルボニル炭素の電子密度が低いことにより, 反応 は容易で速く進む結果, 式 (2) の速度しだいでは, 開環 反応が律速でなくなることも予測される.
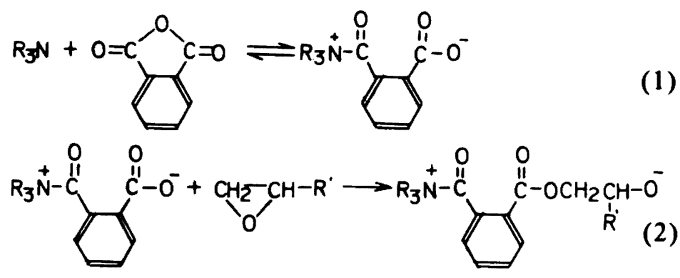

\subsection{EpSO（内部エポキシド）に対する各種酸無水物 の反応性の概要}

各試料 (1～8) の昇温 DSC 法による DSC 曲線を, Fig. 3 に示す. 各試料の発熱ピーク（酸無水物名で表す）は, Cl-MA の $85^{\circ} \mathrm{C}, 3 \mathrm{NO}_{2}$-PA $の 105^{\circ} \mathrm{C}, \mathrm{MA}$ の $110^{\circ} \mathrm{C}$ の他は, $135^{\circ} \mathrm{C}$ 付近に観察される. その中で Me-MA 及び DMe-MA は発熱量が少なく，また，3Me-MA はピーク が高温側にすそを引くことから,これら3者は, 他の酸 無水物より低反応性であることが考えられる. Fig. 3 の 結果から, 酸無水物系の発熱量は PA で $20.5 \mathrm{kcal} \cdot \mathrm{mol}^{-1}$, 3Me-PA で 23.0, 4Me-PA で 25.3, 3NO2-PA で 14.4 及び MA で 27.9, Cl-MA で 19.9, Me-MA で 7.3, DMe-MA で 7.8 が得られた. 発熱量の值に大きなバラッキがでたが, この原因として酸無水物の低反応性や, 高融点 $(3$

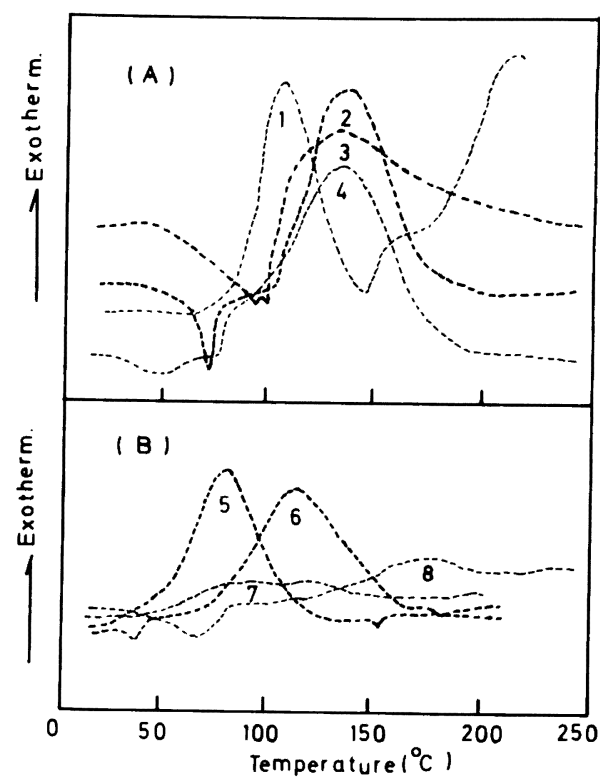

Fig. 3. (A): DSC curves for the curing of EpSO/ Phthalic anhydrides/TEA system (1, 3NO- $-\mathrm{PA} ; 2, \mathrm{PA}$; 3, 3Me-PA; 4, 4Me-PA). (B): DSC curves for the curing of EpSO/Maleic anhydrides/TEA system (5, Cl-MA; 6,MA; 7,Me-MA; 8,DMe-MA).

$\left.\mathrm{NO}_{2}-\mathrm{PA}: 156^{\circ} \mathrm{C}\right)$ のため溶解しないことが挙げられ, 反 応が完結しなかったことが考えられる.このため, 反応 率算出の基準となる標準発熱量は, 前報》の Me-THPA 系 $\left(25.4 \mathrm{kcal} \cdot \mathrm{mol}^{-1}\right)$ を用いた。

Fig. 3 の結果から, 酸無水物系の反応性の順位は Cl-MA $>3 \mathrm{NO}_{2}$-PA $>$ MA $>$ PA, 4Me-PA $>3$ Me-PA $>$ Me-MA, DMe-MA が考えられる.この順序の上位には, $\mathrm{Cl}$ 及び $\mathrm{NO}_{2}$ の電子吸引基をむつ酸無水物があり, 中位 に置換基をもたないMA 及び PA, 電子供与性のメチル 置換体は下位に位置する。 さらに, 3Me-PA と 4Me-PA の発熱ピークの位置は、ほぼ等しいもののピークの高温 側のすそに差があり，このことはメチル基の置換位置の 違いが反応性に影響を及ぼすことを示唆している.

\subsection{EpSO に対する PA 及ひその置換体の反応性}

3.3.1 PA, 3Me-PA, 4Me-PA の反応性 反応温度 $130^{\circ} \mathrm{C}$ の反応率－反応時間の関係を Fig. 4 に示す. 無溶 媒系の 4Me-PA 及び PA の反応率の時間変化はほぼ等し く, 最終反応率は 80〜85\% に達したが、3Me-PA の場合 には反応率が $40 \%$ に達する頃から反応が遅くなり, 最 終反应率は約 60\%にとどまった。 さらに，3Me-PA は Fig. 5 に示すように, 反応温度を高めても反応率の変化 はあまりなく, 反応速度の温度依存性が小さいことが認 められた。

反応速度の解析結果は 4Me-PA 及び PA の場合, ほぼ 
2 次式に適合（反応率約 50\% まで）したが、3Me-PAの 場合は反応初期のみ 2 次式に適合（反応率 $25 \%$ まで）す るにとどまった．その結果を Fig. 6 に示す。また，各反 伈系の速度定数及び活性化ェネルギー, 頻度因子などを Table 2 に示す. 3Me-PA の反応性は 4Me-PA の 1/3 程 度であり, DGEBA との0次反応で両者の反応性が，ほ ぼ等しかった結果 (Table 1) とは大きく異なった結果が 得られた。メチル基の置換位置の違いで, 反応性に差が 生じたことについて， 3.1 で述べた酸無水物の開環反応

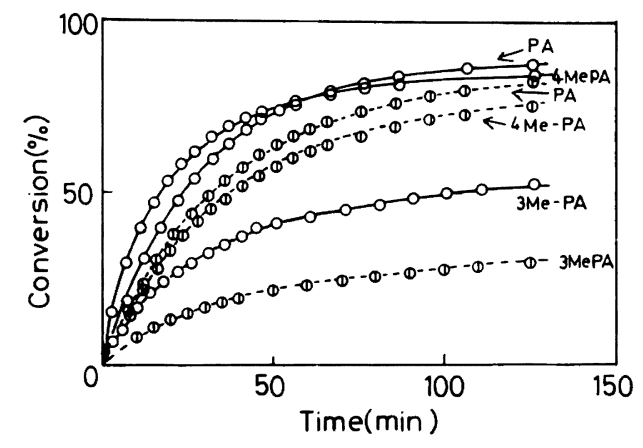

Fig. 4. Time-conversion curves for the curing of EpSO/Phthalic anhydrides/TEA ( $-\mathrm{O}-$, non solvent system at $130^{\circ} \mathrm{C},-\left(1-\right.$, solvent system at $140^{\circ} \mathrm{C}$ ).

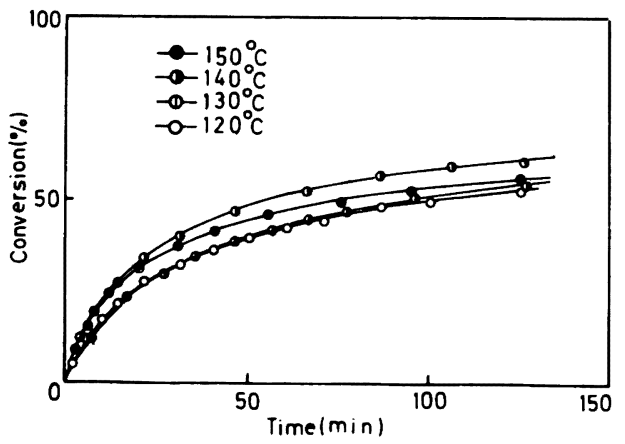

Fig. 5. Time-conversion curves for the curing of EpSO/3Me-PA/TEA system.
機構の推論に基づき, 検討すると以下のことが言える.

2 次反応における酸無水物の反応性は酸無水物が開環 し, 生成したカルボキシルアニオンの性質できまると思 われる.このアニオンに対するメチル基の効果は，その 電子供与性による活性点への寄与と，その立体障害であ り，これらの効果のかね合いで反応性が決まると考えら れる. ところで, 3Me-PA の開環反応 (式 (3)) は, メ千 ル基の電子供与性により，2 位のカルボニル炭素の電子 密度が高まるために，第三アミンの求核攻盤は，比較的 電子密度の低い1 位のカルボニル炭素を, 主に求核攻撃 することが考えられる. その結果, 開環・生成したカル ボキシルアニオンは, メチル基が活性点に隣接する構造 （I）をとるために，立体障害が大きくなる：この立体障 害の程度はメチル基の活性点への I 効果の寄与を上回る ために, 3Me-PA は低反応性を示すものと説明される.
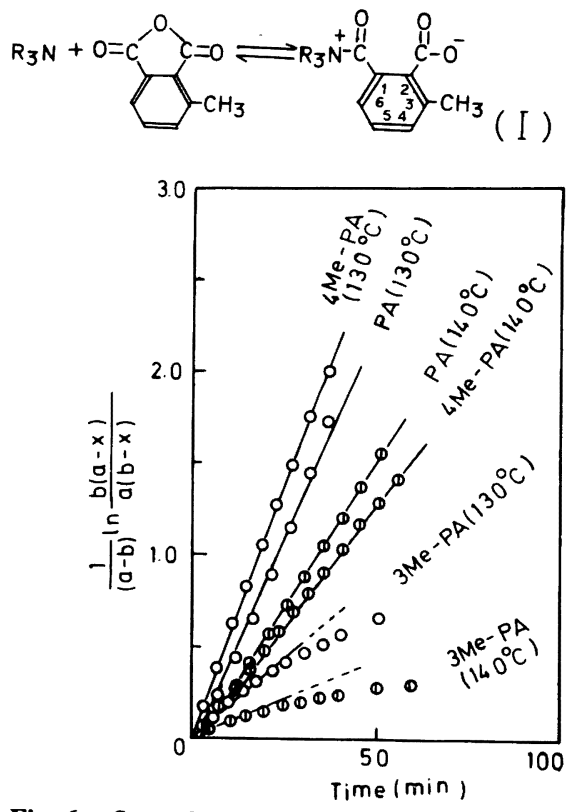

Fig. 6. Second order plots for the curing of EpSO/ Phthalic anhydrides/TEA (- - , non solvent system; $-\mathbb{D}$-, solvent system).

Table 2. Rate constants for the curing of EpSO/Anhydride/TEA (1:1:0.2 mol)

\begin{tabular}{|c|c|c|c|c|c|c|c|c|c|c|}
\hline \multirow{3}{*}{ Anhydride } & \multicolumn{7}{|c|}{$k \times 10^{-4}\left(100 \mathrm{~g} \cdot \mathrm{mol}^{-1} \cdot \mathrm{s}^{-1}\right)$} & \multirow{3}{*}{$\begin{array}{c}E \\
(\mathrm{kcal} / \\
\mathrm{mol})\end{array}$} & \multirow{3}{*}{$\begin{array}{c}A \\
\left(100 \mathrm{~g} \cdot \mathrm{mol}^{-1}\right. \\
\left.\mathrm{s}^{-1}\right)\end{array}$} & \multirow{3}{*}{$\begin{array}{c}\Delta S \\
\text { (e. u) }\end{array}$} \\
\hline & \multicolumn{7}{|c|}{ Temperature $\left({ }^{\circ} \mathrm{C}\right)$} & & & \\
\hline & 90 & 100 & 110 & 120 & 125 & 130 & 135 & & & \\
\hline PA & - & - & - & 4.30 & 6.15 & 7.75 & 10.1 & 17.6 & $2.85 \times 10^{6}$ & -31.7 \\
\hline 4Me-PA & - & - & - & 4.83 & 6.34 & 9.05 & 13.0 & 21.0 & $2.21 \times 10^{8}$ & -22.8 \\
\hline $3 \mathrm{NO}_{2}-\mathrm{PA}$ & 1.84 & 3.53 & 6.23 & $11.0^{\mathrm{a})}$ & $14.5^{\circ)}$ & $18.9^{a)}$ & $24.4^{a)}$ & 16.9 & $2.63 \times 10^{6}$ & -31.4 \\
\hline 3Me-PA & - & - & - & - & - & 2.86 & - & - & - & - \\
\hline
\end{tabular}


一方，4Me-PA の場合も同様な開環機構をたどると考 えられるが,カルボキシルアニオンの立体障害は，活性 点とメチル基が環の炭素原子を一つ隔てた位置にあるた めその影㫼は小さく， メチル基の I 効果の寄与が加わる 分だけ，少しであるが PA の反応性を上回ったと考えら れる. そこで，母体酸無水物に対するメチル置換体 (3 Me-PA, 4Me-PA) の速度定数比 $\left(130^{\circ} \mathrm{C}\right)$ を求めると, 3 $\operatorname{Me}-P A\left(2.86 \times 10^{-4}\right) / P A\left(7.75 \times 10^{-4}\right)=0.37$, 及び 4 $\operatorname{Me}-P A\left(9.05 \times 10^{-4}\right) / P A\left(7.75 \times 10^{-4}\right)=1.2$ となり，これ らの平均値 (等モル混合物) は 0.79 となる.このことか ら, 置換基効果を考えると, メチル基が活性点に隣接し た場合は，立体効果が大きく現れるが (3Me-PA)，それ より環の炭素原子を一つ隔てた位置になると (4 Me-PA), その効果は小さくなり, 代わってメチル基の I 効果の寄与が多少認められると言える。なお，前報4で は母体酸無水物（THPA 及び HHPA）に対するメチル置 換体（3 位及び4 位の混合体之推定される), Me-THPA 及び Me-HHPA の速度定数比は, Me-THPA/THPA= 0.86 及び Me-HHPA/HHPA $=0.84$ となっており, これ らの値は上述の平均値 0.79 に近い値である.

3.3.2 3 $\mathrm{NO}_{2}$-PA の反応性 反応を $3 \mathrm{NO}_{2}$-PA の融点 (mp: $156^{\circ} \mathrm{C}$ 付近 ) 以下の温度で行うために, 従来の無溶 媒系では $3 \mathrm{NO}_{2}-\mathrm{PA}$ が EpSO に完全に溶解しない恐れが あり, 溶媒に二トロベンゼンを用いて行った. 溶媒系の

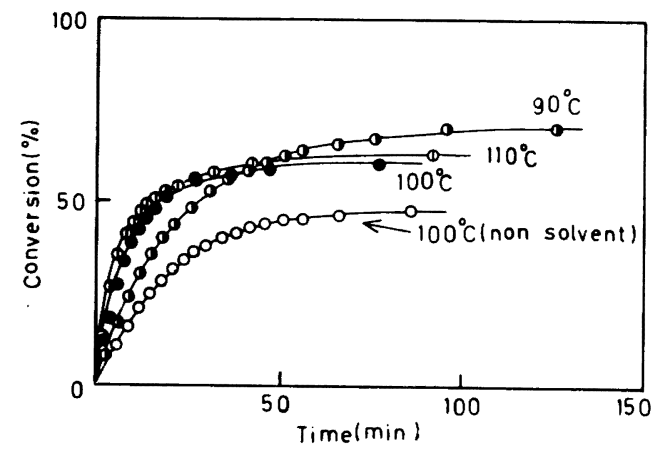

Fig. 7. Time-conversion curves for the curing of EpSO/3NO ${ }_{2}$-PA/TEA (solvent system).
組成 (mol/100 gMix.) は, EpSO: $0.1396 \mathrm{~mol}, 3 \mathrm{NO}_{2}-\mathrm{PA}$ : $0.1469 \mathrm{~mol}$, TEA: $0.0290 \mathrm{~mol}, \mathrm{C}_{6} \mathrm{H}_{5} \mathrm{NO}_{2}: 0.2884 \mathrm{~mol}$ であ る. 反応率一反応時間の関係を Fig. 7 に, $1 /(a-b) \cdot \ln b$ $(a-x) / a(b-x)$ と反応時間の関係を Fig. 8 に示す. また, 速度定数の值を Table 3 に示す. $3 \mathrm{NO}_{2}$-PA は他の酸無水 物より高反応性で, このことは無溶媒系 (Table 2) につ いても同様であり，その理由としては以下のことが言え る.

$3 \mathrm{NO}_{2}$-PA の開環反応（式 (4)）はニト口基の電子吸引 性により, 2 位のカルボニル炭素の電子密度が, 1 位に比 べてより低くなるので, この炭素に第三アミンが求核付 加し, 開環する結果, カルボキシルアニオンは, 主に構 造 (II) が生成すると考えられる. また, (II) は構造 (III) のように, 電子密度の高い活性点とニトロ基が隣接して おらず，負の電子同志の反発による不安定化がないだ け，(II) のエネルギー状態は低いと考えられ，この観点 からも (II) の生成が優先すると指摘される.

ところで, アニオン (II) の活性点は, ニトロ基が環の 炭素原子を一つ隔てた位置にあるため，4Me-PA の例に 類似して立体障害は小さく反応性が高いことが推測され る. さらに, 活性点は二ト口基の電子吸引性 (I 効果) に より，付加した第三アミンの電子供与性（3 個のエチル

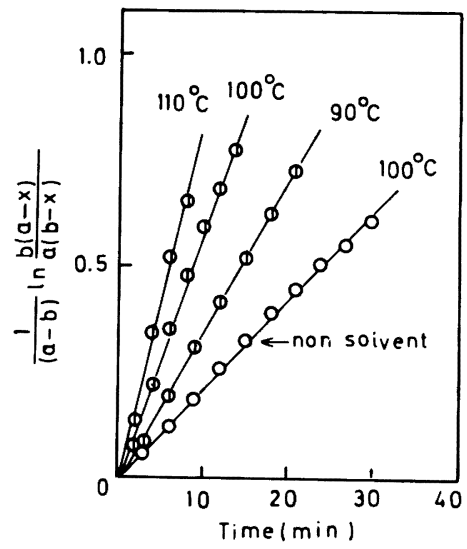

Fig. 8. Second order plots for the curing of EpSO/ $3 \mathrm{NO}_{2}$-PA/TEA (solvent system).

Table 3. Rate constants for the curing of EpSO/Anhydride/TEA (solvent system)

\begin{tabular}{|c|c|c|c|c|c|c|c|c|c|c|}
\hline \multirow{3}{*}{ Anhydride } & \multicolumn{7}{|c|}{$k \times 10^{-4}\left(100 \mathrm{~g} \cdot \mathrm{mol}^{-1} \cdot \mathrm{s}^{-1}\right)$} & \multirow{3}{*}{$\begin{array}{c}E \\
\text { (kcal/ } \\
\text { mol) }\end{array}$} & \multirow{3}{*}{$\begin{array}{c}A \\
\left(100 \mathrm{~g} \cdot \mathrm{mol}^{-1}\right. \\
\left.\mathrm{s}^{-1}\right)\end{array}$} & \multirow{3}{*}{$\begin{array}{c}\Delta S \\
\text { (e. u) }\end{array}$} \\
\hline & \multicolumn{7}{|c|}{ Temperature $\left({ }^{\circ} \mathrm{C}\right)$} & & & \\
\hline & 90 & 100 & 110 & 140 & 145 & 150 & 155 & & & \\
\hline PA & - & - & - & 5.23 & 6.23 & 7.08 & 9.48 & 13.4 & $6.39 \times 10^{3}$ & -43.8 \\
\hline 4Me-PA & - & - & - & 4.32 & 5.76 & 6.53 & 8.12 & 14.2 & $1.38 \times 10^{4}$ & -42.2 \\
\hline $3 \mathrm{NO}_{2}-\mathrm{PA}$ & 5.93 & 9.68 & 14.3 & - & - & - & - & 12.2 & $1.25 \times 10^{4}$ & -42.1 \\
\hline 3Me-PA & - & - & - & 1.13 & - & - & - & - & - & - \\
\hline
\end{tabular}


基）が促進され，その効果はニトロ基がアニオン活性点 の電子密度を低くする効果を上回ると考えられるため, 活性点の電子密度（塩基性）は高く, 反応性が高くなる と言える. 一般に, 第三アミンの触媒効果は, 電子供与 性の置換基を有するアミン程, 大きいことが報告されて おり"，その効果を促進する二ト口基の存在が，この場 合, 反応性に寄与していると解釈できる.
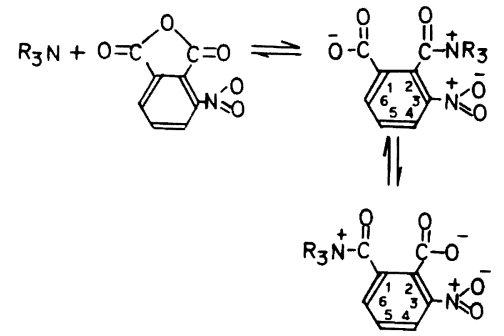

他方，アニオン (II) の活性は二ト口基の共鳴安定効果 により，その反応性はある程度の低下が予測されるが， 実際には，この効果の影響がない母体酸無水物及び立体 効果の類似する 4Me-PA の反応性を上回ったことから， ニト口基の共鳴効果の影響は小さく，それに比へてて，上 述のI効果の奇与の大きいことが示唆される.

このように 3.1 で述へた酸無水物の開環反応機構に基 づくと，各種酸無水物の反応性の実験結果を説明でき， 開環反応機構の推論は合理性があることが証明される.

Table 2, 3 の結果から, 無水フタル酸置換体の反応性の

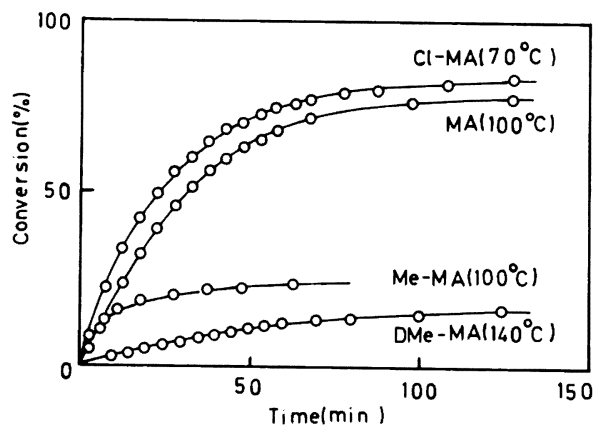

Fig. 9. Time-conversion curves for the curing of EpSO/Maleic anhydrides/TEA system.
順序は 3NO

3.4 EpSO に対する無水マレイン酸系の反応性及ひ 総括

反応率一反応時間の関係を Fig. 9 に示す. Cl-MA $\left(70^{\circ} \mathrm{C}\right)$ 及び MA $\left(100^{\circ} \mathrm{C}\right)$ の最終反応率は $80 \%$ 前後に達 して高反応性であるのに対し, Me-MA $\left(100^{\circ} \mathrm{C}\right)$ は $30 \%$ 弱及び DMe-MA $\left(140^{\circ} \mathrm{C}\right)$ は $20 \%$ 前後にとどまり，低反 応性であることが分かった．次に，反応速度の解析結果 を Fig. 10 に示す. Cl-MA 及び MA の反応速度はほぼ 2 次式に適合し, 得られた速度定数の値を Table 4 に示す。 一方, Me-MA, DMe-MA の場合は 2 次式へ適合せず，他 の次数についても同様であった。この両者の反応が特定 の反応次数に適合しなかったことは，無水フタル酸のメ チル置換体 (3Me-PA) の例に類似であることから，それ は活性点に隣接したメチル基の立体障害のためであると 考えられる。

Fig. 9 及び Table 4 の結果から, 無水マレイン酸置換 体の反応性の順序は, Cl-MA > MA > Me-MA > DMe-MA となり，この順序は電子吸引性の置換基をも つ酸無水物 >母体酸無水物 >そのメチル置換体となり, 無水フタル酸及びその置換体の場合に類似の傾向であ る.

これまでの無水フタル酸系及び無水マレイン酸系の実 験結果を総括すると，エポキシ化大豆油に対する酸無水

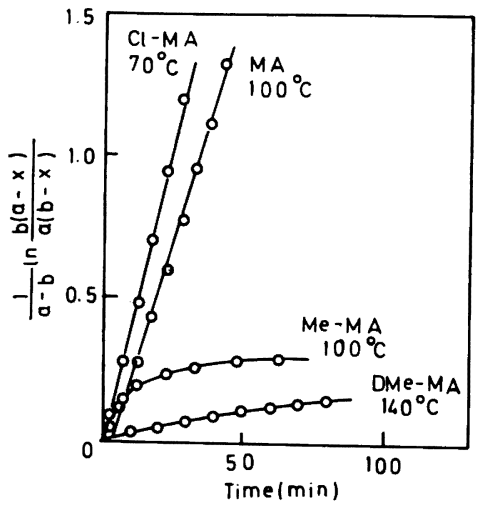

Fig. 10. Second order plots for the curing of EpSO/ Maleic anhydrides/TEA system.

Table 4. Rate constants for the curing of EpSO/Anhydride/TEA (1:1:0.2 mol)

\begin{tabular}{|c|c|c|c|c|c|c|c|c|c|}
\hline \multirow{3}{*}{ Anhydride } & \multicolumn{6}{|c|}{$k \times 10^{-4}\left(100 \mathrm{~g} \cdot \mathrm{mol}^{-1} \cdot \mathrm{s}^{-1}\right)$} & \multirow{3}{*}{$\begin{array}{c}E \\
\text { (kcal/ } \\
\text { mol) }\end{array}$} & \multirow{3}{*}{$\begin{array}{c}A \\
\left(100 \mathrm{~g} \cdot \mathrm{mol}^{-1}\right. \\
\left.\mathrm{s}^{-1}\right)\end{array}$} & \multirow{3}{*}{$\begin{array}{c}\Delta S \\
\text { (e.u) }\end{array}$} \\
\hline & \multicolumn{6}{|c|}{ Temperature $\left({ }^{\circ} \mathrm{C}\right)$} & & & \\
\hline & 70 & 80 & 90 & 100 & 110 & 120 & & & \\
\hline MA & - & - & - & 5.46 & 11.2 & 20.8 & 19.5 & $1.56 \times 10^{8}$ & -23.6 \\
\hline Cl-MA & 7.44 & 14.9 & 29.2 & - & - & - & 17.0 & $4.92 \times 10^{7}$ & -25.7 \\
\hline
\end{tabular}


物の反応性の傾向として, $\mathrm{Cl}-\mathrm{MA}>3 \mathrm{NO}_{2}-\mathrm{PA}>\mathrm{MA}>4$ Me-PA, PA $>$ Me-MA $>3$ Me-PA $>$ DMe-MA が得られ た. この順序で無水マレイン酸及びその置換体が，無水 フタル酸及びその置換体より反応性が高いことについて は，両者の立体効果に大差ない場合は，無水マレイン酸 系のカルボキシルアニオンの共鳴安定性が、ベンゼン環 との共役結合をもつ無水フタル酸系よりも小さく，その ぶん安定性に欠けるため, 反応性が高いと言える.

また，エポキシ化大豆油と種々の酸無水物の反応は多 くが 2 次式に適合し，末端エポキシドである DGEBAの 0次反応とは異なったが、これはエポキシ化大豆油の低 反応性に起因するものと思わ机る。すすなわち，立体障害 の大きな内部エポキシ基と, 酸無水物の開環反応で生じ たカルボキシルアニオンの求核反応 (2 次) は, 酸無水物 の開環反応 (0 次) に比べて反応の進行はかなり遅く、そ のため律速反応になったと考えられる. その目安とし $\tau$, EpSO/PA/TEA $(1: 1: 0.2 \mathrm{~mol})$ 系の, 2 次反応初速 度 $\left(120^{\circ} \mathrm{C}: v=1.03 \times 10^{-4} \mathrm{~mol} \cdot 100 \mathrm{~g}^{-1} \cdot \mathrm{s}^{-1}\right)$ と, DGEBA/ PA/TEA $(1: 1: 0.2 \mathrm{~mol})$ 系の, 開環反応初速度 $\left(110^{\circ} \mathrm{C}\right.$, $\left.v=4.00 \times 10^{-4} \mathrm{~mol} \cdot 100 \mathrm{~g}^{-1} \cdot \mathrm{s}^{-1}\right)$ を比較した場合, 2 次反 応の初速度は反応温度が $10^{\circ} \mathrm{C}$ 高いにも関わらず, 開環 反応よりも遅く，同じ反応温度に換算すると約 $1 / 7$ の速 度であり，そのため律速段階になったと推定される。

以上のように，エポキシ化大豆油と各種の酸無水物の 硬化反応は，ほとんどの場合が 2 次反応で進行したた め, 酸無水物の反応性は，カルボキシルアニオンの反応 性に対応した傾向が得られたものと推定できる。

\section{4 結 論}

第三アミンを促進剤に用いた DGEBA と酸無水物 (PA, Me-PA 系) の硬化反応は，酸無水物の開環反応加 律速反応 (0 次) となり, 各種酸無水物の反応性に大きな 差は認められなかった。この結果から酸無水物の開環反 応は, 第三アミンが電子密度の低い方のカルボニル炭素 （酸無水基）を選択的に求核攻撃し，開環すると推定し た.

一方，エポキシ化大豆油と各種酸無水物（PA 系, MA 系）の反応は, エポキシ基と酸無水物の濃度に依存する 2 次反応が律速となり, 酸無水物の反応性は, 電子吸引

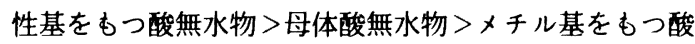
無水物の順位になった：この反応性の傾向は酸無水物の 開環反応で生成した，カルボキシルアニオンの分子構造 に起因すると推察され，このアニオンに対する置換基効 果は, I 効果及び共鳴効果よりも，立体効果の影響が大 きいことが認められた。

\section{文献}

1) Y. Tanaka and H. Kakiuchi, J. Appl. Polym. Sci., 7, 1063 (1963).

2) Y. Tanaka and H. Kakiuchi, J. Polym. Sci., A, 2, 3405 (1964).

3) R. F. Fischer, J. Polym. Sci., 44, 155 (1960).

4) 小又基彰，渡辺茂隆。高分子論文集，49,601 (1992).

The Reactivity and the Ring-Opening Reaction Mechanism for Various Substituted Acid Anhydrides of EpoxideAnhydride Reaction

Motoaki Komata*1 and Shigetaka WatanaBE*1

*1 Department of Systems Engineering, Faculty of Engineering, Ibaraki University (Nakanarusawa 4-12-1, Hitachi, Ibaraki, 316 Japan)

The curing reaction of the epoxidized soybean oil (internal epoxide) with substituted phthalic anhydrides and maleic anhydrides was studied using tertiary amine as accelerator. The purpose was to elucidate the substituent effects (inductive, resonance, and steric) on the reactivity of acid anhydrides to epoxides. The reactivity of anhydrides was increased by the presence of electron attractive groups $\left(\mathrm{Cl}, \mathrm{NO}_{2}\right)$ as substituents. In the presence of an electron donating group $\left(\mathrm{CH}_{3}\right)$, the reactivity of anhydrides depended on the position of substituents. Namely, the reactivity of 4-methylphthalic anhydride increased a little, whereas that of 3-methylphthalic anhydride decreased. The reactivity of anhydrides was much more affected by the steric hindrance, which results from the position of substituent, than by the inductive effect ( $I$ effect) of substituents. The reactivity appeared to be governed by the structure of the carboxyl anion which was formed from the ring-opening reaction. In the curing reaction of diglycidyl ether of bisphenol A (DGEBA) (external epoxide) with substituted phthalic anhydrides, the rate-determining step was the ring-opening reaction (zero-order reaction), and almost no recognizable difference was observed in the reactivity of anhydrides. The ring-opening reaction mechanism of anhydride was also examined.

KEY WORDS Epoxide-Anhydride Reaction/Substituted Phthalic Anhydride/Maleic Anhydride/Substituent Effect / Ring-Opening Reaction /

(Received February 5, 1992: Accepted April 11, 1992)

[Kobunshi Ronbunshu, 49(7), 609-615 (1992)] 